\title{
ANALISIS TINGKAT KETERBACAAN WACANA BUKU TEKS \\ PELAJARAN BAHASA INDONESIA KURIKULUM2013 REVISI 2017 DENGAN MENGGUNAKAN TEKNIK FOG INDEKSSISWA KELAS VIIISMP NEGERI 18 MEDAN TAHUN PEMBELAJARAN 2017/2018
}

\author{
Irwandi Silalahi(irwandisilalahi684@gmail.com)
}

Fitriani Lubis, S.Pd., M.Pd. (rianiavandi@gmail.com)

\begin{abstract}
ABSTRAK
Penelitian ini bertujuan untuk mengetahui dan menentukan tingkat keterbacaan wacana buku teks pelajaran Bahasa Indonesia kurikulum 2013 revisi 2017 dengan menggunakan teknik Fog Indeks siswa kelas VIII SMP Negeri 18 Medan Tahun Pembelajaran 2017/2018. Jenis penelitian ini merupakan penelitian deskriptif yaitu untuk mendeskripsikan data penelitian dengan apa adanya. Penelitian ini difokuskan pada tingkat keterbacaan wacana buku teks pelajaran Bahasa Indonesia kurikulum 2013 revisi 2017 kelas VIII SMP Negeri 18 Medan. Teknik pengumpulan data pada penelitian dilakukan dengan teknik tes.Tes yang digunakan adalah tes FogIndeks. Data dianalisis dengan teknik analisis deskriptif, yaitu mendeskripsikan tingkat keterbacaan wacana buku teks pelajaran Bahasa Indonesia kurikulum 2013 revisi 2017 dengan menggunakan teknik Fog Indeks siswa kelas VIII SMP Negeri 18 Medan Tahun Pembelajaran 2017/2018. Berdasarkan hasil penelitian, maka dapat disimpulkan bahwa tingkat keterbacaan wacana buku teks pelajaran Bahasa Indonesia kurikulum 2013 revisi 2017 siswa kelas VIII SMP Negeri 18 Medan tahun pembelajaran 2017/2018 memiliki nilai rata-rata Fog Indeks 3.53 termasuk dalam tingkat keterbacaan tinggi, yakni mudah dipahami oleh siswa.
\end{abstract}

Kata Kunci: analisis, keterbacaan wacana, dan Fog Indeks

\section{PENDAHULUAN}

Di dalam proses pembelajaran, salah satu faktor penunjang untuk keberhasilan pembelajaran Bahasa Indonesia di sekolah adalah buku teks pelajaran. Tarigan dan Tarigan (2009: 13) mengatakan bahwa "Buku teks adalah buku pelajaran dalam bidang studi tertentu yang merupakan buku standar, yang disusun oleh pakar dalam bidang itu buat maksud-maksud dan tujuan instruksional, yang diperlengkapi dengan sarana-sarana pengajaran yang serasi dan mudah dipahami oleh para pemakainya di sekolah-sekolah dan perguruan tinggi sehingga dapat menunjang sesuatu program pengajaran". Oleh karena itu, kehadiran buku teks pelajaran sangat mempengaruhi proses belajar mengajar di 
kelas karena pada buku teks pelajaran sudah memuat maksud-maksud dan tujuan instruksional yang menjadi acuan/pedoman keberhasilan pembelajaran di sekolah.

Ada beberapa kriteria buku teks pelajaran dapat dikatakan berkualitas tingggi. Greene dan Petty (dalam Tarigan dan Tarigan, 2009: 20) merumuskan butir-butir dalam penilaian buku teks yaitu: 1) buku teks itu haruslah menarik minat anak-anak, yaitu para siswa mempergunakannya; 2) buku teks itu haruslah mampu memberi motivasi kepada para siswa yang memakainya; 3) buku teks itu haruslah memuat ilustrasi yang menarik hati para siswa yang memanfaatkannya; 4) buku teks itu seyogianyalah mempertimbangkan aspek-aspek linguistik sehingga sesuai dengan kemampuan para siswa yang memakainya; 5) buku teks itu isinya haruslah berhubungan erat dengan pelajaran-pelajaran lainnya; lebih baik lagi kalau dapat menunjangnya dengan rencana, sehingga semuanya merupakan suatu kebulatan yang utuh dan terpadu; 6) buku teks itu haruslah dapat menstimulasi, merangsang aktivitas-aktivitas pribadi para siswa yang mempergunakannya; 7) buku teks itu haruslah dengan sadar dan tegas menghindari konsep-konsep yang samar-samar dan tidak biasa, agar tidak sempat membingungkan para siswa yang memakainya; 8) buku teks itu haruslah mempunyai sudut pandangan atau "point of view" yang jelas dan tegas sehingga juga pada akhirnya menjadi sudut pandangan para pemakainya yang setia; 9) buku teks itu haruslah mampu memberi pemantapan, penekanan pada nilai-nilai anak dan orang dewasa; 10) buku teks itu haruslah dapat menghargai perbedaanperbedaan pribadi para siswa pemakainya.

Salah satu penilaian buku teks pelajaran berkualitas tinggi adalah buku teks pelajaran harus mempertimbangkan aspek-aspek linguistik sehingga sesuai dengan kemampuan para siswa yang memakainya.Kriteria tersebut karena memuat materi-materi yang disajikan secara komunikatif.Mursini (2012: 41) mengemukakan bahwa "Ragam bahasa yang digunakan dalam bahan ajar (buku teks) biasanya ragam bahasa komunikatif yang lugas dan luwes”.Komunikatif, artinya bahasa yang digunakan dapat membuat peserta didik merasa seolah-olah berinteraksi dengan gurunya sendiri melalui tulisan-tulisan yang disampaikan dalam buku teks pelajaran. Walaupun komunikatif, kaidah bahasa yang baik dan 
benar tidak ditinggalkan atau dilanggar.Hal ini sangat perlu sebagai salah satu persyaratan dari keterbacaan bahan ajar yang ditulis dan dikembangkan.

Sitepu (2015: 120) mengatakan bahwa "Keterbacaan yang dimaksud dalam penulisan buku teks pelajaran adalah sejauh mana siswa dapat memahami bahan pelajaran yang disampaikan dengan bahasa ragam tulis".Dalam ragam bahasa tulisan, pikiran, gagasan, dan perasaan itu dinyatakan dalam bentuk huruf/angka, kata, frase, dan kalimat.Dilihat dari makna, kata merupakan unit terkecil dalam bahasa.Melalui kaidah tertentu kata disusun menjadi kalimat sehingga mengandung makna yang lebih lengkap. Jadi, untuk memahami suatu bahasa, perlu mengetahui makna kata dan tata cara menyusunnya sehingga menjadi kalimat yang mengandung arti yang lengkap.

Kata merupakan unsur terkecil dalam kalimat, tetapi mengandung makna yang mempengaruhi pemahaman keseluruhan kalimat.Kalau makna satu kata tidak dipahami atau salah dipahami dapat mengakibatkan kesalahan memahami keseluruhan isi kalimat.Oleh karena itu, kata-kata yang dipakai dalam penulisan buku teks pelajaran hendaknya yang sudah biasa dipakai dan dipahami dengan baik oleh siswa.Kata-kata baru yang berupa istilah dalam bidang ilmu tertentu tidak bisa dihindari, karena itu diberikan penjelasan yang lengkap sehingga siswa memahaminya dengan baik.

Memilih kata dengan makna yang tepat serta dipahami siswa menjadi sulit, ketika buku teks dimaksudkan digunakan secara nasional, sedangkan kosakata yang dimiliki siswa beraneka ragam.Misalnya, ada kata-kata yang sudah dipahami siswa di daerah perkotaan, tetapi masih asing bagi mereka yang tinggal di pedesaan. Kata seperti "canggih", "mengunduh", dan surat elektronik" sering didengar dan dipahami oleh siswa yang tinggal di kota, tetapi tidak pernah atau jarang didengar dan dipakai oleh mereka yang tinggal di desa sehingga tidak mengerti maknanya.

Kesulitan memilih kata yang dipahami oleh siswa secara nasional dapat juga terjadi karena perbedaan lingkungan.Kata "berselancar" dan "berjemur" mungkin sulit dipahami oleh siswa yang tinggal di daerah pegunungan, tetapi 
biasa bagi yang tinggal di daerah pantai karena beragamnya kosakata yang dipakai dan dipahami oleh siswa di seluruh Indonesia.Kata yang sudah terbiasa dipakai di pulau jawa misalnya, masih asing di pulau Kalimantan, dan sebaliknya.Kata yang dipilih hendaknya jenis kata yang singkat dan lugas, bukan kata atau istilah yang asing atau tidak banyak dikenal oleh siswa.

Sungguh pun terdapat berbagai kesulitan, penulis buku teks pelajaran perlu menyadari masalah pilihan kata dalam menulis buku teks pelajaran.Pemilihan kata yang singkat, jelas, menarik dapat memudahkan siswa memahami isi bacaan maka tingkat keterbacaan itu tinggi.Sebaliknya, jika kata-kata itu asing dan kosakata kompleks dapat menyulitkan siswa memahami isi bacaan, maka tingkat keterbacaan itu rendah karena sukar dibaca sehingga pembaca merasa bosan.Buku teks pelajaran yang baik haruslah menyajikan materi yang menarik, mudah dipahami, dan memiliki tingkat keterbacaan yang tinggi.

Dalam Peraturan Menteri Pendidikan dan Kebudayaan Republik Indonesia Nomor 8 Tahun 2016 Pasal 1 ayat 1 menyebutkan bahwa "Buku teks pelajaran adalah sumber pembelajaran utama untuk mencapai kompetensi dasar dan kompetensi inti dan dinyatakan layak oleh Kementerian Pendidikan dan Kebudayaan untuk digunakan pada satuan pendidikan. Oleh karena itu, penyajian materi harus ditata dengan menarik, mudah dipahami, dan memiliki tingkat keterbacaan yang tinggi, dan memenuhi nilai/norma positif yang berlaku di masyarakat antara lain tidak mengandung unsur pornografi, paham ekstrimisme, radikalisme, kekerasan, SARA, bias gender, dan tidak mengandung nilai penyimpangan lainnya".

Sesuai dengan peraturan pemerintah, buku teks pelajaran yang akan diterbitkan oleh pemerintah haruslah menyajikan materi yang menarik, mudah dipahami dan memiliki tingkat keterbacaan yang tinggi. Tampubolon (2016: 213) mengemukakan bahwa "Secara praktis, untuk mengetahui keterbacaan suatu bacaan dapat diketahui dari jawaban atas pertanyaan-pertanyaan berikut. a. Apakah kata-kata dalam bacaan itu mudah atau sukar? b. Apakah kalimat-kalimat bacaan itu sederhana atau kompleks? c. Apakah isi bacaan itu menarik hati pembaca atau tidak. Jika jawaban pertanyaan-pertanyaan itu berturut-turut (a) 
sukar, (b) kompleks, dan (c) tidak, maka secara umum dapat dikatakan bahwa tingkat keterbacaan bacaan itu rendah, dan karena itu sukar dibaca. Jika jawabanjawaban adalah sebaliknya, maka bacaan itu dapat dikatakan mudah".

Pada kenyataannya buku teks pelajaran Bahasa Indonesia kurikulum 2013 yang diterbitkan oleh pemerintah sulit dipahami karena kata-kata sukar dan memiliki kalimat-kalimat yang panjang/kompleks, maka bacaan itu dapat dikatakan memiliki tingkat keterbacaan yang rendah. Hal tersebut didapatkan dari hasil kuesioner dengan siswa kelas VIII-2 SMP Negeri 18 Medan Tahun Pembelajaran 2017/2018 dengan jumlah siswa, yaitu 34 orang. Hasilnya menunjukkan bahwa tingkat keterbacaan tinggi atau bahan bacaan itu mudah dan sederhana, ada 12 siswa atau sekitar 35,3\% sedangkan ada 22 siswa atau sekitar 64,7\% yang menunjukkan bahwa bacaan itu sukar dan kompleks atau memiliki tingkat keterbacaan rendah. Dengan demikian, hasil kuesioner menunjukkan bahwa buku teks pelajaran kurikulum 2013 yang diterbitkan oleh pemerintah sulit dipahami oleh siswa, maka tingkat keterbacaannya rendah.

Berdasarkan hasil observasi yang dilakukan dan wawancara terhadap seorang guru Bahasa Indonesia di SMP Negeri 18 Medan, yaitu Ibu Lies Hanurani Sibuea, S.Pd. Beliau mengatakan bahwa sekitar separuh siswa yang kurang mampu memahami sebuah wacana atau teks. Biasanya, faktor yang menghambat siswa dalam memahami teks adalah kosakata kompleks, wacana yang terlalu panjang, kalimatnya yang panjang, dan siswa tidak serius dalam mengikuti proses pembelajaran.

Penelitian yang dilakukan oleh Gumono (2016) yang berjudul “Analisis Tingkat Keterbacaan Buku Siswa Bahasa Indonesia Kelas VII Berbasis Kurikulum 2013”.'Hasil penelitiannya menunjukkan bahwa dari 38 judul teks, terdapat 20 (52\%) judul teks yang sesuai dengan siswa kelas VII SMP dan sebanyak 18 (48\%) judul teks memiliki keterbacaan yang tidak memenuhi syarat. Teks yang memiliki keterbacaan yang tidak sesuai dapat digolongkan menjadi dua jenis yaitu teks yang terlalu mudah dan teks yang terlalu sulit.Teks dengan tingkat keterbacaan yang terlalu mudah memiliki jumlah sebanyak 1 judul teks. Untuk teks yang memiliki tingkat keterbacaan yang terlalu sulit sebanyak 17 judul 
teks.Hal tersebut menunjukkan bahwa lebih dari setengah dari jumlah keseluruhan teks dalam buku tersebut yang memenuhi syarat. Penelitian yang dilakukan Yeni Lisnawati (2017) dengan judul "Tingkat Keterbacaan Wacana Nonfiksi pada Buku Teks Bahasa Indonesia Pegangan Siswa Kelas VII SMP Negeri 5 Raha Kurikulum 2013 Edisi Revisi 2014 dengan Menggunakan Teknik Isian Rumpang”. Hasil penelitiannya menunjukkan bahwa wacana nonfiksi dalam buku teks bahasa Indonesia kurikulum 2013 edisi revisi 2014 semuanya belum cukup baik untuk siswa kelas VII di SMP Negeri 5 Raha.

Terukurnya tingkat keterbacaan sangat penting dalam upaya membuat siswa paham tentang isi teks atau wacana yang disajikan.Dalam hal ini, perlunya dilakukan analisis tingkat keterbacaan buku teks pelajaran kurikulum 2013. Ketidaksesuain buku teks pelajaran dengan kemampuan siswa dapat dipastikan pembelajaran tidak akan berjalan dengan maksimal, maka keberhasilan dalam mencapai tujuan pembelajaran pun tidak akan berjalan dengan baik.Untuk mengukur keterbacaan berbagai faktor perlu dipertimbangkan, seperti struktur bahasa, (kosakata dan kalimat), jenis isi bacaan, tipografi, dan minat pembaca.Cara-cara yang telah ada pada umumnya untuk mengukur keterbacaan hanya dari segi struktur bahasa. Dalam mengukur keterbacaan, berbagai formula keterbacaan yang dapat digunakan, seperti Reading Ease Formula (REF), Human Interst (HI), Fog Indeks (FI), Grafik Fry, Grafik Raygor, dan Cloze (Teknik Isian Rumpang). Formula-formula tersebut mampu digunakan untuk mengukur tingkat keterbacaan.Teknik Fog Indeks dapat digunakan untuk melihat tingkat keterbacaan wacana dari pemahaman kalimat siswa.Formula Fog Indeks ini dapat memberikan gambaran awal tentang tingkat keterbacaan tulisan dalam buku teks pelajaran.

Formula ini ditemukan pakar dan praktisi media Amerika Serikat, Robert Gunning (1952).Fog secara harfiah berarti "kabut" yang digambarkan sebagai penghalang mata pembaca untuk melihat (memahami) suatu wacana.Adapun "indeks" berarti angka atau jumlah. Semakin banyak kabut maka akan semakin sukar sebuah wacana untuk dimengerti. Menurut hasil observasi Gunning (dalam Masri, 2013: 43) mengemukakan bahwa "Faktor penghalang atau kabut tersebut 
berupa "big words", yakni kata-kata yang sukar, tidak populer, bersuku kata lebih dari tiga, serta menggunakan kalimat majemuk dan terdiri atas lebih dari 11 kata per kalimat".

Gunning menuangkan formula temuannya pada buku The Technique of Clear Writing (1952).Pada awal mula, uji coba keterbacaan wacan hanya media yang berbasis bahasa Inggris saja. Akan tetapi kemudian, karena temuan itu berlaku universal, Fog Indeks pun dapat diterapkan untuk wacana yang berbahasa non-Inggris, termasuk bahasa Indonesia. Dari hasil penelitian yang dilakukan oleh KN, Yasa, dkk. (2013) yang berjudul "Kecermatan Formula Flesh, Fog Index, Grafik Fry, Smog, dan BI sebagai Penentu Keefektifan Teks Berbahasa Indonesia”. Hasil penelitian menunjukkan bahwa: (1) formula yang berbasis Bahasa Inggris dan Formula BI cermat menetukan keterbacaan teks berbahasa Indonesia, (2) kecermatan antara formula berbasis Bahasa Inggris dan Formula BI tidak berbeda secara signifikan, dalam artian sama-sama cermat.

Dengan demikian, penelitian ini secara khusus mengkaji "Analisis Tingkat Keterbacaan Wacana Buku Teks Pelajaran Kurikulum 2013 Revisi 2017 dengan Menggunakan Teknik Fog Indeks Siswa Kelas VIII SMP Negeri 18 Medan Tahun Pembelajaran 2017/2018”. Dengan mengetahui tingkat keterbacaan buku teks, maka dapat diperoleh deskripsi tingkat keterbacaan wacana buku teks pelajaran bahasa indonesia kurikulum 2013 revisi 2017 dengan menggunakan teknik Fog Indeks siswa kelas VIII SMP Negeri 18 Medan tahun pembelajaran 2017/2018. Hal ini bermanfaat untuk mengetahui tingkat kemampuan membaca siswa serta dapat memberikan penilian terhadap buku teks pelajaran yang digunakan, sebagai tolak ukur keberhasilan belajar siswa bagi guru, sedangkan bagi sekolah, penelitian ini diharapkan dapat mempertimbangkan dalam memilih buku teks yang akan digunakan dalam kegiatan pembelajaran.

\section{METODE PENELITIAN}

Penelitian ini menggunakan metode penelitian analisis deskriptif.Deskripsi diperoleh dari data yang dikumpulkan melalui teknik Fog Indeks dan kemudian dianalisis secara statistik.Populasi dalam penelitian ini adalah keseluruhan siswa 
kelas VIII SMP Negeri 18 Medan Tahun Pembelajaran 2017/2018.Sampel penelitian ini adalah mengambil satu kelas, yaitu kelas VIII-2yang berjumlah 34 orang untuk menjadi sampel penelitian.

Data dalam penelitian ini adalah isian dan skor dari tes Fog Indeks yang bersumber dari wacana buku teks pelajaran Bahasa Indonesia kurikuum 2013 revisi 2017.Sumber data dalam penelitian adalah wacana buku teks pelajaran Bahasa Indonesia kurikuum 2013 revisi 2017 kelas VIII.Wacana yang digunakan sebagai sumber data adalah wacana yang memenuhi kriteria untuk digunakan sebagai tes Fog Indeks.Teknik pengumpulan data pada penelitian ini dilakukan dengan teknik tes.Tes yang digunakan adalah tes Fog Indeks.Pengumpulan data dengan tes Fog Indeks adalah sebagai berikut: siswa diminta memberikan skor untuk setiap kalimat mulai dari kategori mudah sampai kategori sulit dan waktu yang digunakan untuk mengerjakan tes Fog Indeksadalah dua belas menit per wacana ditambah dengan delapan menit untuk penjelasan dan pengisian data responden sehingga total waktu yang digunakan adalah 80 menit. Selanjutnya, penulis menganalisis hasil tes yang telah dilakukan sesuai prosedur analisis tes Fog Indeks.Penulis menganalisis isian siswa berdasarkan kategori dan persentase setiap kategori.

\section{HASIL PENELITIAN DAN PEMBAHASAN}

\section{A. Hasil Penelitian}

Dalam penelitian ini data yang akan dideskripsikan adalah tingkat keterbacaan wacana buku teks pelajaran Bahasa Indonesia kurikulum 2013 revisi 2017 dengan menggunakan teknik Fog Indeks siswa kelas VIII SMP Negeri 18 Medan tahun pembelajaran 2017/2018.

Terdapat 6 tes Fog Indeks yang diteskan kepada siswa, yang terdiri atas tiga wacana narasi, dua wacana eksposisi, dan satu wacana eksplanasi dari semester ganjil dan semester genap. Jumlah kalimat yang terdapat pada enam wacana tersebut adalah 72 kalimat, yaitu wacana 1 teks berita sebanyak 13 kalimat, wacana 2 teks eksposisi sebanyak 11 kalimat, wacana 3 teks eksplanasi sebanyak 18 kalimat, wacana 4 teks ulasan sebanyak 7 kalimat, wacana 5 teks 
persuasif sebanyak 11 kalimat, dan wacana 6 teks gemar membaca sebanyak 12 kalimat.

Berdasarkan skor keterbacaan wacana buku teks pelajaran Bahasa Indonesia kurikulum 2013 revisi 2017 kelas VIII yang terdiri dari 6 wacana dapat disimpulkan bahwa tingkat keterbacaan wacana buku teks pelajaran Bahasa Indonesia yang digunakan siswa kelas VIII SMP Negeri 18 Medan memiliki tingkat keterbacaan tinggi dengan rata-rata persentase yaitu 3.53. Adapun rekapitulasi hasil uji tes Fog Indeks dapat dilihat sebagai berikut.

Tabel 1.Rekapitulasi Hasil Uji Tes Fog Indeks

\begin{tabular}{|c|c|c|}
\hline Wacana & Skor Keterbacaan & Tingkat Keterbacaan \\
\hline Wacana 1 & 3.02 & Tinggi \\
\hline Wacana 2 & 3.58 & Tinggi \\
\hline Wacana 3 & 2.31 & Tinggi \\
\hline Wacana 4 & 5.31 & Tinggi \\
\hline Wacana 5 & 3.76 & Tinggi \\
\hline Wacana 6 & 3.25 & Tinggi \\
\hline N=6 & $\mathbf{2 1 . 2 3}$ & - \\
\hline Rata-rata & $\mathbf{3 . 5 3}$ & - \\
\hline \multicolumn{2}{|c|}{ Tingkat Keterbacaan } & Tinggi \\
\hline
\end{tabular}

Untuk mengetahui tingkat kesulitan kalimat, penulis akan mencari beberapa temuan untuk mendapatkan faktor-faktor yang mempengaruhinya. Di bawah ini penulis akan mengelompokkan kalimat jawaban sulit dengan persentase terbanyak. Kalimat berkategori sulit ini dapat dilihat pada tabel berikut.

Tabel 2.Pengelompokkan Kalimat Kategori Sulit Per Wacana

\begin{tabular}{|c|c|c|c|c|c|}
\hline \multirow[b]{2}{*}{ No. } & \multirow[b]{2}{*}{ Kalimat } & \multirow{2}{*}{$\begin{array}{l}\text { Persentase } \\
\text { jawaban } \\
\text { sulit }\end{array}$} & \multicolumn{3}{|c|}{ Tingkat kesulitan } \\
\hline & & & PK1 & SK & PK2 \\
\hline 1. & $\begin{array}{l}\text { Andai tak ada cinta diantara mereka, } \\
\text { bisa jadi pemakaman ini seperti pekerjaan } \\
\text { sepele yang lain, seperti mengganti } \\
\text { tabung dispenser, menyapu daun kering di } \\
\text { halaman, atau menyobek kertas tagihan } \\
\text { telepon yang kedaluarsa. }\end{array}$ & $76.5 \%$ & $\sqrt{ }$ & & \\
\hline 2. & $\begin{array}{l}\text { "Jadi, masuk jalan Fatmawati Raya, } \\
\text { kemudian masuk jalan Cipete, dan masuk } \\
\text { jalan Haji Jian, "kata petugas Pemadam } \\
\text { Kebakaran Sudin Jakarta, Dendi. }\end{array}$ & $73.5 \%$ & & $\sqrt{ }$ & \\
\hline
\end{tabular}




\begin{tabular}{|c|c|c|c|c|c|}
\hline 3. & $\begin{array}{l}\text { Adanya konflik-konflik seperti konflik } \\
\text { antarmasyarakat lokal, masyarakat lokal } \\
\text { dengan perusahaan, atau antara } \\
\text { masyarakat lokal dengan Pemerintah, } \\
\text { semakin memperburuk kondisi kehutanan } \\
\text { di Indonesia. }\end{array}$ & $70.6 \%$ & $\sqrt{ }$ & & \\
\hline 4. & $\begin{array}{l}\quad \text { Keterpurukan sektor kehutanan } \\
\text { bersumber dari sistem pengelolaan yang } \\
\text { didominasi oleh pemerintah pusat dan } \\
\text { mengesampingkan } \\
\text { masyarakat lokal. }\end{array}$ & $58.8 \%$ & $\sqrt{ }$ & & \\
\hline 5. & $\begin{array}{l}\text { Produsen dan konsumen akan } \\
\text { menggunakan sebagian dari energinya } \\
\text { untuk aktivitas hidup seperti tumbuh, } \\
\text { reproduksi, respirasi, dan sebagainya. }\end{array}$ & $58.8 \%$ & & & $\sqrt{ }$ \\
\hline 6. & $\begin{array}{l}\text { Nah, yang paling penting nih, kita bisa } \\
\text { bertanggung jawab atas pilihan tadi } \\
\text { sehingga tidak akan menyesal dikemudian } \\
\text { hari. }\end{array}$ & $58.2 \%$ & $\sqrt{ }$ & & \\
\hline 7. & $\begin{array}{l}\text { Dia selalu flash back ke masa kecilnya } \\
\text { dulu sewaktu masih SD Muhammadiyah } \\
\text { yang sederhana dengan dua guru yang } \\
\text { bersahaja, Bu Muslimah (Cut Mini) dan } \\
\text { Pak Harfan (Ikranagar). }\end{array}$ & $55.9 \%$ & $\sqrt{ }$ & & \\
\hline 8. & $\begin{array}{l}\text { Lima tahun berlalu dan film bercerita } \\
\text { tentang anggota Laskar Pelangi kelimanya } \\
\text { duduk di kelas } \mathrm{V} \text {, melalui sudut pandang } \\
\text { Ikal kecil (Zulfani). }\end{array}$ & $52.9 \%$ & $\sqrt{ }$ & & \\
\hline 9. & $\begin{array}{l}\text { Produktivitas ekosistem terbagi dua, } \\
\text { yakni produktivitas primer dan } \\
\text { produktivitas sekunder. }\end{array}$ & $50 \%$ & & & $\sqrt{ }$ \\
\hline 10. & $\begin{array}{l}\text { Energi ini disimpan dalam bentuk zat } \\
\text { organik yang dapat digunakan sebagai } \\
\text { bahan makanan dan disebut prosuksi } \\
\text { primer. }\end{array}$ & $47.1 \%$ & & & $\sqrt{ }$ \\
\hline 11. & $\begin{array}{l}\text { Selain Ikal, ada juga tokoh Lintang } \\
\text { (Ferdian) yang amat jenius dan Mahar } \\
\text { (Verrys Yamarno) yang menunjukkan } \\
\text { bakat seni luar biasa. }\end{array}$ & $41.2 \%$ & $\sqrt{ }$ & & \\
\hline 12. & $\begin{array}{l}\text { Mobil-mobil itu menyebar dan } \\
\text { berusaha menjangkau lokasi kebakaran } \\
\text { dari segala penjuru mata angin, mencari } \\
\text { jalan tercepat. }\end{array}$ & $44.1 \%$ & & $\sqrt{ }$ & \\
\hline 13. & $\begin{array}{l}\text { Dari, utara, barat, timur, kita kerahkan } \\
\text { supaya mana yang lebih dulu sampai } \\
\text { langsung bisa menangani. }\end{array}$ & $44.1 \%$ & & $\sqrt{ }$ & \\
\hline 14. & $\begin{array}{l}\text { Diperburuk lagi dengan rencana } \\
\text { pembukaan lahan hutan lindung bagi } \\
\text { pertambangan. }\end{array}$ & $44.1 \%$ & & & $\sqrt{ }$ \\
\hline 15. & $\begin{array}{l}\text { Energi kimia mengalir dari produsen } \\
\text { ke konsumen dari berbagai tingkat trofik } \\
\text { melalui jalur rantai makanan. }\end{array}$ & $38.2 \%$ & & & $\sqrt{ }$ \\
\hline
\end{tabular}


Keterangan:

PK1 : Panjang Kalimat

SK : Susunan Kalimat

PK2 : Pilihan Kata

\section{B. Pembahasan}

Adapun hasil penelitian yang dilakukan di SMP Negeri 18 Medan menunjukkan bahwa wacana buku teks pelajaran Bahasa Indonesia kelas VIII dengan jumlah responden 34 orang memiliki tingkat keterbacaan yang tinggi. Wacana 1 dengan indeks keterbacaan 3.02, wacana 2 sebesar 3.58. wacana 3 sebesar 2.31, wacana 4 sebesar 5.31, wacana 5 sebesar 3.76, dan wacana 6 sebesar 3.25 .

Dari hasil yang diperoleh wacana yang paling mudah adalah wacana 3 dengan indeks keterbacaan 2.31. Kalimat yang dianggap mudah disebabkan oleh beberapa faktor antara lain sebagai berikut.

Kalimat (4): Energi kimia mengalir dari produsen ke konsumen dari berbagai tingkat trofik melalui jalur rantai makanan.

Kalimat (8): Produktivitas ekosistem terbagi dua, yakni produktivitas primer dan produktivitas sekunder.

Kalimat (10): Produsen dan konsumen akan menggunakan sebagian dari energinya untuk aktivitas hidup seperti tumbuh, reproduksi, respirasi, dan sebagainya.

Kalimat (13): Energi ini disimpan dalam bentuk zat organik yang dapat digunakan sebagai bahan makanan dan disebut prosuksi primer.

Pilihan kata yang dianggap sulit oleh siswa, yakni istilah asing yang sering dipakai penulis dalam wacana itu, seperti "biotik, trofik, reproduksi, respirasi, primer, sekunder, klorofil, fotosintesis, dan parameter". Banyaknya kata dan istilah baru atau tidak sering digunakan oleh siswa menyebabkan sulit untuk memahami wacana tersebut. 
Pada wacana yang paling sulit adalah wacana 4 dengan indeks keterbacaan 5.31. Kalimat yang dianggap sulit disebabkan oleh beberapa faktor antara lain sebagai berikut.Pada wacana 4 memiliki 7 kalimat per 100 kata dengan indeks keterbacaan 5.31.Ada 3 kalimat yang dianggap sulit oleh siswa karena memiliki kalimat yang panjang. Kalimat yang panjang tersebut adalah:

Kalimat (4): Dia selalu flash back ke masa kecilnya dulu sewaktu masih SD Muhammadiyah yang sederhana dengan dua guru yang bersahaja, Bu Muslimah (Cut Mini) dan Pak Harfan (Ikranagar).

Kalimat (5): Lima tahun berlalu dan film bercerita tentang anggota Laskar Pelangi kelimanya duduk di kelas $\mathrm{V}$, melalui sudut pandang Ikal kecil (Zulfani).

Kalimat (6): Selain Ikal, ada juga tokoh Lintang (Ferdian) yang amat jenius dan Mahar (Verrys Yamarno) yang menunjukkan bakat seni luar biasa.

Adanya empat kalimat yang dianggap sulit dipahami atau memiliki tingkat keterbacaan rendah dipengaruhi oleh banyaknya kata asing, kata berulang di samping banyaknya kata yang membangun kalimat tersebut.

\section{SIMPULAN}

Berdasarkan hasil analisis data yang diperoleh dari penelitian, maka dapat disimpulkan bahwa tingkat keterbacaan wacana buku teks pelajaran Bahasa Indonesia kurikulum 2013 revisi 2017 siswa kelas VIII SMP Negeri 18 Medan tahun pembelajaran 2017/2018 memiliki nilai rata-rata Fog Indeks 3.53. Berdasarakan kategori penilaian pemerolehan nilai rata-rata 3.53 termasuk dalam tingkat keterbacaan tinggi, yakni mudah dipahami oleh siswa.Tinggi/rendahnya tingkat keterbacaan wacana dapat dipengaruhi oleh tiga faktor, yakni jumlah kata, jumlah kalimat, dan jumlah kata-kata sukar.

Agar keterbacaannya mudah dan sesuai dengan pemahaman siswa, penulis buku harus mencermati kembali tulisannya dan memperbaikinya dengan 
mengganti atau menambahi kalimat-kalimat yang pendek menjadi panjang tetapi jangan terlalu panjang sehingga sesuai dengan jenjang pendidikannya.Penulis ataupun sekolah atau guru hendaknya mengukur terlebih dahulu tingkat keterbacaan suatu buku teks pelajaran dengan karakteristik pemahaman siswanya atau dengan jenjang pendidikan siswanya.

\section{DAFTAR PUSTAKA}

Mursini. 2012. "Pengembangan Bahan Ajar Bahasa dan Sastra Indonesia". Medan: Unimed Press

Sitepu.Bintang P. 2015. "Penulisan Buku Teks Pelajaran". Bandung: Remaja Rosdakarya

Somadayo, Samsu. 2011. "Strategi dan Teknik Pembelajaran Membaca". Yogyakarta: Graha Ilmu

Tampubolon. 2016. "Kemampuan Membaca: Teknik Membaca Efektif dan Efisien". Bandung: Angkasa

Tarigan, Henry Guntur dan Djago Tarigan. 2009. "Telaah Buku Teks Bahasa Indonesia". Bandung: Angkasa

Lisnawati, Yeni. 2017. "Tingkat Keterbacaan Wacana Nonfiksi pada Buku Teks Bahasa Indonesia Pegangan Siswa Kelas VII SMP Negeri 5 Raha Kurikulum 2013 Edisi Revisi 2014 dengan Menggunakan Teknik Isian Rumpang”. Jurnal Bastra 1 (4), hal. 1-17

Gumono. 2016. "Analisis Tingkat Keterbacaan Buku Siswa Bahasa Indonesia Kelas VII Berbasis Kurikulum 2013”. Diksa: Jurnal Pendidikan Bahasa dan Sastra Indonesia 2 (2), hal. 132-141

Putra, Sareb Masri. 2013. "Fog Index dan Keterbacaan Berita Utama (Headline) Suara Merdeka 03 Mei 2013”. Jurnal Ilmu Komunikasi 8 (1), hal. 41-48

Peraturan Menteri Pendidikan dan Kebudayaan Republik Indonesia Nomor 8 Tahun 2016 Tentang Buku yang Digunakan Oleh Satuan Pendidikan 